\title{
Specify Other KRAS Codon Mutation
}

National Cancer Institute

\section{Source}

National Cancer Institute. Specify Other KRAS Codon Mutation. NCI Thesaurus. Code C158890.

A request to enter the specific KRAS codon where a mutation was identified in the study but it is not present in the form. 